\title{
Interdisciplinary on-site evaluation of stone bunds to control soil erosion on cropland in Northern Ethiopia
}

\author{
Jan Nyssen ${ }^{\text {a,b,c,* }, \text { Jean Poesen }}{ }^{\mathrm{c}}$, Desta Gebremichael ${ }^{\mathrm{c}, \mathrm{d}}$, Karen Vancampenhout ${ }^{\mathrm{a}}$, \\ Margo D'aes ${ }^{\mathrm{e}}$, Gebremedhin Yihdego ${ }^{\mathrm{f}}$, Gerard Govers ${ }^{\mathrm{c}}$, Herwig Leirs ${ }^{\mathrm{e}}$, \\ Jan Moeyersons ${ }^{\mathrm{g}}$, Jozef Naudts ${ }^{\mathrm{a}, \mathrm{h}}$, Nigussie Haregeweyn ${ }^{\mathrm{b}, \mathrm{c}}$, \\ Mitiku Haile ${ }^{\mathrm{c}}$, Jozef Deckers ${ }^{\mathrm{a}}$ \\ ${ }^{a}$ Division Soil and Water Management, K.U. Leuven, Celestijnenlaan 200E, B-3001 Heverlee, Belgium \\ ${ }^{\mathrm{b}}$ Department of Land Resources Management and Environmental Protection, \\ Mekelle University, P.O. Box 231, Mekelle, Ethiopia \\ ${ }^{\mathrm{c}}$ Physical and Regional Geography Research Group, K.U. Leuven, Celestijnenlaan 200E, \\ B-3001 Heverlee, Belgium \\ ${ }^{\mathrm{d}}$ Relief Society of Tigray, P.O. Box 20, Mekelle, Ethiopia \\ ${ }^{\mathrm{e}}$ Department of Biology, Evolutionary Biology Group, University of Antwerp, Antwerp, Belgium \\ ${ }^{\mathrm{f}}$ Faculty of Business and Economics, Mekelle University, P.O. Box 231, Mekelle, Ethiopia \\ ${ }^{\mathrm{g}}$ Department of Agriculture and Forestry Economics, Royal Museum for Central Africa, \\ B-3080 Tervuren, Belgium \\ ${ }^{\mathrm{h}}$ ADCS Food Security Project, P.O. Box 163, Adigrat, Ethiopia
}

Received 11 November 2005; received in revised form 28 June 2006; accepted 16 July 2006

\begin{abstract}
Since two decades, stone bunds have been installed in large areas of the Tigray Highlands, Northern Ethiopia, to control soil erosion by water. Field studies were conducted to quantify the effectiveness, efficiency, side effects and acceptance of stone bunds. Based on measurements on 202 field parcels, average sediment accumulation rate behind 3-21 year old stone bunds is $58 \mathrm{tha}^{-1}$ year $^{-1}$.The Universal Soil Loss Equation's $P$-factor for stone bunds was estimated at 0.32 . Sediment accumulation rates increase with slope gradient and bund spacing, but decrease with bund age. Truncation of the soil profile at the lower side of the bund does not lead to an important soil fertility decrease, mainly because the dominant soil types in the study area (Regosols, Vertisols and Vertic Cambisols) do not have pronounced vertical fertility gradients. Excessive removal of small rock fragments from the soil surface during stone bund building may lead to a three-fold increase in sheet and rill erosion rates. Negative effects of runoff concentration or crop burial by sediment deposition due to bunds were only found over $60 \mathrm{~m}$ along $4 \mathrm{~km}$ of studied bunds. As the rodent problem is widespread and generally not specific to stone bunds, it calls for distinct interventions. On plots with stone bunds of different ages (between 3 and 21 years old), there is an average increase in grain yield of 53\% in the lower part of the plot, as compared to the central and upper parts. Taking into account the space occupied by the bunds, stone bunds led in 2002 to a mean crop yield increase from 0.58 to $0.65 \mathrm{t} \mathrm{ha}^{-1}$. The cost of stone bund building averages $€ 13.6 \mathrm{ha}^{-1}$ year $^{-1}$, which is nearly the same as the value of the induced crop yield increase in $2002\left(€ 13.2 \mathrm{ha}^{-1}\right.$ year $\left.^{-1}\right)$. Besides positive off-site effects such as runoff and flood regulation, the enhanced moisture storage in deep soil horizons on both sides of the bunds indicates that the stone bund areas can be made more productive through tree planting. We conclude that from the technical, ecological and economical point of view, the extensive use of stone bunds, involving people's participation, is a positive operation. Overall, $75 \%$ of the farmers are in favour of
\end{abstract}

\footnotetext{
* Corresponding author at: Division Soil and Water Management, K.U. Leuven, Celestijnenlaan 200E, B-3001 Heverlee, Belgium.

E-mail address: jan.nyssen@biw.kuleuven.be (J. Nyssen).
} 
stone bund building on their land, which is a clear indication that the local community perceives this conservation measure as being beneficial.

(C) 2006 Elsevier B.V. All rights reserved.

Keywords: Soil and water conservation; Tigray; Crop yield; Surface rock fragments; Progressive terraces; Rodent infestations

\section{Introduction}

According to the annual report by the Tigray Bureau of Agriculture and Natural Resource (BoANR, 2002), 522,600 ha of land in the Tigray Highlands, Northern Ethiopia (Fig. 1) have been treated by different soil and water conservation measures, especially stone bunds (Fig. 2), between 1991 and 2002. For this purpose, the farmers build $0.3-1.2 \mathrm{~m}$ high walls along the contour with large rock fragments $(10-40 \mathrm{~cm})$, using mediumsized rock fragments $(5-10 \mathrm{~cm})$ as backfill. Finally, the backfill is topped with stone-rich soil or with small rock fragments (average diameter $2 \mathrm{~cm}$ ), which act as a filter for coarse sediment during major rainfall events (Nyssen et al., 2001). Off-site effects of stone bund implementation are definitely positive: improved hydrological conditions in the catchment and strongly

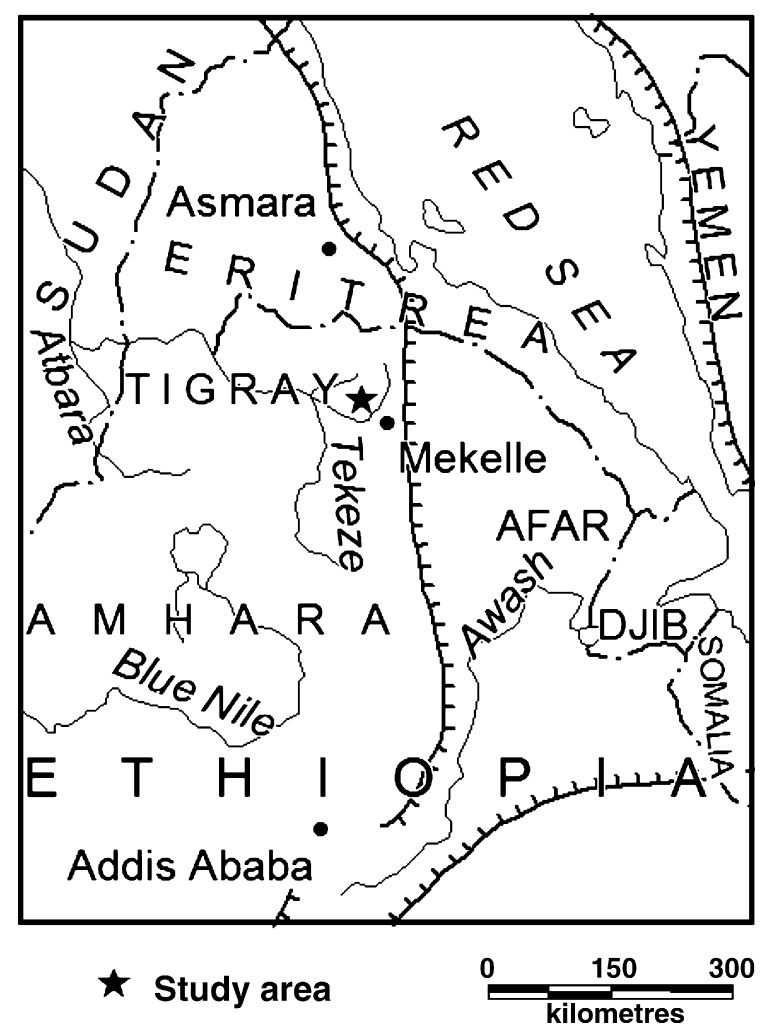

Fig. 1. Location of the study area, Dogu'a Tembien in Northern Ethiopia. decreased specific sediment yield were measured in reservoirs with catchments that have a high density of stone bunds (Nigussie et al., 2005). Yet, the on-site effects are more difficult to assess and call for a careful analysis based on field data. Attempts to assess effectiveness of stone bunds in Tigray through model applications appear unreliable (Hengsdijk et al., 2005; Nyssen et al., 2006a).

The on-site impacts of stone bunds on erosion can be classified into short- and long-term effects based on the time needed to become effective against soil erosion (Morgan, 1995; Bosshart, 1997). According to Bosshart (1997), the potential short-term benefits of stone bunds are the reduction of slope length and the creation of small retention basins for runoff and sediment. They therefore reduce the volume and erosivity of the overland flow. These effects appear immediately after the construction of the stone bunds and result in reduced soil loss. The medium and long-term benefits, according to this study, include the reduction in hillslope gradient by progressive terrace formation, the development of vegetation cover on the bunds themselves and the change in land management. Based on studies of the Soil Conservation Research Project (SCRP) in Central, Western and Southern Ethiopia, Herweg and Stillhardt (1999) state that well-established mechanical soil and water conservation (SWC) structures retain most of the soil eroded in between the structures. The studies mentioned above were carried out on erosion plots and

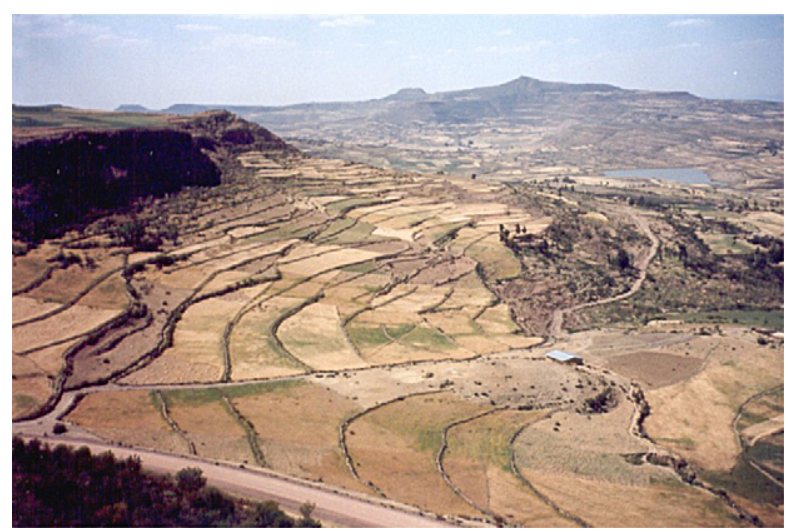

Fig. 2. Stone bunds on cropland in May Leiba catchment, $12 \mathrm{~km} \mathrm{E}$ of Hagere Selam town. 
dealt with well-managed young stone bunds. Hence, a first aspect of evaluation is the on-site effectiveness of these structures in trapping sediment and in reducing soil erosion in real field situations where stone bund positioning may not always be optimal and where effects need to be considered over a time span of decades. Furthermore, at the landscape scale, stone bunds may lead to the concentration of runoff in convergent landscape positions and hence increase the gully erosion hazard.

As the importance of rock fragment cover in protecting arable land from soil erosion by water is well known (Wischmeier and Smith, 1978; Poesen et al., 1994), it was also important to study the effect of rock fragment removal from the topsoil for bund building.

In the long term, slow-forming terraces induced by stone bunds are often associated with a high spatial variability in soil fertility and crop response, due to the erosion and accumulation processes mentioned above. Especially when the fertility is concentrated in the top layer of the soil, truncation of the profile by tillage erosion (Turkelboom et al., 1997; Nyssen et al., 2000a) at the upper part of the field exposes a less fertile subsoil layer (Dercon et al., 2003). A dramatic drop in crop yield may then result from such fertility gradients and may therefore pose a limitation to the long-term crop productivity of these systems. This problem remains a dominant issue in the debate about the sustainability of slow forming terraces (Turkelboom et al., 1999; Herweg and Ludi, 1999; Dabney et al., 1999; Dercon et al., 2003).

However, stone bunds may also offer potential to stem erosion-induced crop productivity losses (Lal, 1998; Den Biggelaar et al., 2004). In addition, the soil strips along stone bunds have a potential for increasing biomass production.

Another important aspect of stone bund sustainability is direct damage to crops due to accumulation of sediment, concentration of runoff by the structures and the presence of rats in the structures (Gebremedhin and Herweg, 2000).

Finally, it proved important to go beyond sometimes superficial assessments of farmers' perception of soil and water conservation techniques and to carry out in depth participatory research on acceptance of stone bunds.

The objective of this paper is to synthesise previous (published and unpublished) studies quantifying the effectiveness, efficiency, side effects and acceptance of stone bunds in Tigray, Ethiopia. We analyse available information, mainly obtained from research on farmers' fields, with respect to the various effects stone bunds have on soil and water conservation, crop productivity, the presence of rat infestations and the potential for introducing agroforestry in the context of the Ethiopian Highlands. We also investigate how the building of stone bunds is perceived by the local farmers as acceptance is an important factor in the adoption and maintenance of soil conservation structures (Herweg, 1993; Tenge et al., 2004).

\section{Materials and methods}

\subsection{Study area}

These studies on stone bunds were conducted in the northern Ethiopian Highlands and more specifically in Dogu'a Tembien district (Fig. 1) around the market town Hagere Selam, located at an altitude of $2650 \mathrm{~m}$ a.s.l., about $50 \mathrm{~km}$ to the west of Mekelle, capital city of Tigray region.

The main rainy season $(>80 \%$ of total rainfall) extends from June to September but is sometimes preceded by 3 months of dispersed less intense rains. Average yearly precipitation is $769 \mathrm{~mm}$. Field measurements show that rain is highest nearby cliffs and other eminent slopes, perpendicular to the main valleys, which are preferred flow paths for the air masses. Rain erosivity is high due to the occurrence of large drop sizes, which results in higher rain kinetic energy than elsewhere in the world (Nyssen et al., 2005).

The local geology comprises subhorizontal series of alternating hard and soft Antalo limestone layers, some $400 \mathrm{~m}$ thick, overlain by Amba Aradam sandstone (Hutchinson and Engels, 1970). Two series of Tertiary lava flows, separated by silicified lacustrine deposits (Merla, 1938; Arkin et al., 1971; Merla et al., 1979) bury these Mesozoic sedimentary rocks.

Differential erosion, in response to the Miocene and Plio-Pleistocene tectonic uplifts (in the order of $2500 \mathrm{~m}$ ), resulted in the formation of tabular, stepped landforms, reflecting the subhorizontal geological structure. The uppermost levels of the landscape at about 2700-2800 m a.s.l. are formed in the basalt series. Other structural levels correspond to the top of the Amba Aradam sandstone and to the top of hard layers within the Antalo limestone (Nyssen et al., 2002).

Permanently cropped fields are the dominant land use and cover-ca. 65\%, of the study area (Fig. 2). The agricultural system in the Northern Ethiopian Highlands has been characterised as a 'grain-plough complex' (Westphal, 1975). The main crops are barley (Hordeum vulgare L.), wheat (Triticum sp.) and tef 
(Eragrostis tef), an endemic cereal crop. Various species of pulses are also an important part of the crop rotation. Soil tillage is carried out with ox-drawn ard ploughs (Nyssen et al., 2000a; Solomon et al., 2006). Steep slopes (i.e. $>0.3 \mathrm{~m} \mathrm{~m}^{-1}$ ) are mainly under rangeland, parts of which have been set aside recently to allow vegetation regrowth (Descheemaeker et al., 2006).

The Regional government of Tigray and local NGOs have implemented different types of stone bunds on cropland as well as on rangeland in all parts of the district. As a result, the larger part of Dogu'a Tembien district is terraced with stone bunds dating from different periods. Dogu'a Tembien is representative for the Northern Ethiopian Highlands, particularly the Tigray highlands and midlands (approximately $40,000 \mathrm{~km}^{2}$ and 3.5 million inhabitants). Bund spacing depends on the slope gradient, according to widely distributed guidelines (e.g. BoANR, 1997; reproduced in Nyssen et al., 2000b). Obviously, there is some variability in bund spacing as farmers tend to construct the bunds on plot boundaries or integrate them with preexisting lynchets in a bid to find a good compromise between the space occupied by bunds and their effectiveness. Introduction of agroforestry trees on stone bunds has generally failed in the study region, mainly for lack of protection from browsing livestock, which has its origin in the practice of stubble grazing (Hailu, 2003).

\subsection{Effectiveness of stone bunds for soil and water conservation}

Qualitative and quantitative assessments of soil loss and sediment accumulation rates were based on measurements of morphological characteristics of 202 study plots, bounded on their upper and lower side by stone bunds constructed 3-21 years ago.

The average front height of the bunds was $0.74 \pm 0.19 \mathrm{~m}$ and the average ratio of front height over horizontal offset was 3.74 (Desta, 2003). Building material were basalt rock fragments for 139 bunds and sand- or limestone rock fragments for 63 bunds. No maintenance had been done on 32 bunds, one maintenance on 107 bunds and two maintenance operations on 61 bunds. During maintenance operations, collapsed parts are rebuilt and when the depression behind the bund is filled with sediment, the height is increased. On average, a maintenance operation results in a height increase by $0.08 \mathrm{~m}$. Twenty-eight percent of the studied bunds were perfectly constructed on the contour, and only $12 \%$ showed a deviation from the contour exceeding $0.03 \mathrm{~m} \mathrm{~m}^{-1}$. A small strip of farmland is left unploughed on both sides of the bunds for stabilisation: on average $0.25 \mathrm{~m}$ on the upper side and $0.37 \mathrm{~m}$ on the lower side. For many farmers, extending the cropped area is the only way to increase production, which leads to narrowing of these support strips over time (Desta, 2003).

The soil profile at the foot of a bund is truncated by tillage erosion and the foundation of the bunds is generally exposed (Fig. 3, left). A tillage step with a triangular cross-section represents the truncated profile (Turkelboom et al., 1997; Desta et al., 2005). The lengths of the sides of this cross-section with their respective slope gradients were measured and the crosssectional area calculated (Desta et al., 2005). The soil transport rate by tillage erosion was calculated as the product of the cross-sectional area of the tillage step, average length of bunds per hectare of cropland, dry bulk density of the soil and age of the bunds in that area, and expressed in $\mathrm{t} \mathrm{ha}^{-1}$ year $^{-1}$ (Desta et al., 2005).

Volumes of sediment accumulated behind the upper stone bunds (Fig. 3, right) were measured and related to bund dimensions as well as to their age and to environmental characteristics of the sites.

Intraplot soil loss due to sheet and rill erosion $\left(A_{\text {intra, }}\right.$, $\mathrm{t} \mathrm{ha}^{-1}$ year $^{-1}$ ) was predicted by applying the Universal Soil Loss Equation (USLE) model (Wischmeier and Smith, 1978) to the 202 study plots (Desta et al., 2005).

The mean annual soil loss $\left(A, \mathrm{t} \mathrm{ha}^{-1}\right.$ year $\left.^{-1}\right)$ from cropland with bunds was then calculated from the
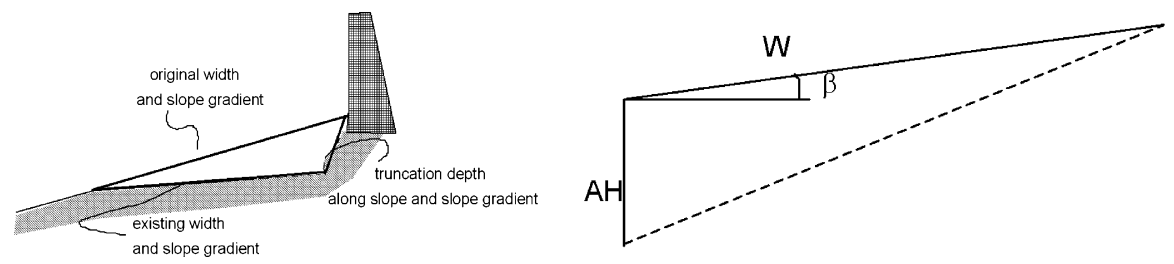

Fig. 3. Cross-sectional area of truncated soil or 'tillage step' at foot of the stone bund, with measured dimensions (left). The accumulation (right) was measured using the accumulation width $(W)$, the accumulation height behind the stone bund $(\mathrm{AH})$ and the slope gradient $(\beta)$ of the $\mathrm{AZ}($ after Desta et al., 2005). 
measured sediment accumulation behind the stone bunds, the estimated intraplot soil loss due to sheet and rill erosion and measured tillage erosion rates.

Soil loss due to sheet and rill erosion before bund construction was assumed similar to the present sheet and rill erosion rates calculated for the central zone of the plots treated with the bunds. The reduction of erosion rates due to the reduction of slope length by stone bund building was assumed to be compensated for by the increase of erosion due to rock fragment removal and the clear water effect.

Finally, the USLE sub-factor for stone bunds, $P_{\mathrm{N}}$ was calculated as:

$P_{\mathrm{N}}=\frac{A}{A_{\text {intra }}} \quad$ (Desta et al., 2005)

We also assessed spatial and temporal variability of gravimetric soil moisture content in the area around the bunds on four representative plots (Vancampenhout et al., 2006).

\subsection{Effects of stone bunds on soil fertility}

In-depth studies on the spatial variability of soil fertility of terraced land were conducted as well. Measurements of $\mathrm{pH}_{\left(\mathrm{H}_{2} \mathrm{O}\right)}, \mathrm{pH}_{(\mathrm{KCl})}$, total nitrogen $\left(\mathrm{N}_{\text {tot }}\right)$, total carbon $\left(\mathrm{C}_{\mathrm{tot}}\right)$ and $\mathrm{CaCO}_{3}$ content of the topsoil were taken along the slope on 20 representative plots. Organic carbon content $\left(\mathrm{C}_{\text {org }}\right)$ was computed from $\mathrm{C}_{\text {tot }}$ and $\mathrm{CaCO}_{3}$ (Vancampenhout et al., 2006).

\subsection{Consequences of rock fragment removal}

The effects of rock fragment removal on soil loss were investigated on runoff plots (Nyssen et al., 2001). Three treatments were compared: natural rock fragment cover, and half or all the rock fragments removed by hand. Rock fragment cover was measured in the field by the point-count method. At the foot of each subplot the eroded soil was trapped in stonewalled collector trenches. After the runoff water in the trenches infiltrated and evaporated and before the clay-rich sediment started cracking, the volume and mass of sediment trapped in the trenches at the foot of the subplots was measured (Nyssen et al., 2001).

\subsection{Effects of stone bunds on runoff and sediment accumulation}

Possible crop damage related to runoff concentration and sediment accumulation were recorded during the rainy season of 2002 along $4 \mathrm{~km}$ of stone bunds in various topographic positions. Phenomena such as crop root exposure, crop burial by sediment, as well as rill and gully development after stone bund collapse, were recorded and analysed in a quantitative way (Vancampenhout, 2003).

\subsection{Impact of stone bunds on rodent dynamics}

Numbers and characteristics of rat populations in areas with high and low densities of stone bunds were compared in 2005 (D'aes, 2006). For this purpose, two trapping sessions of four consecutive nights each were organised with a mixture of Sherman live traps and snap traps on eight sites $(60 \mathrm{~m} \times 60 \mathrm{~m})$ with differences in stone bund density, soil type and number of stone heaps. The first trapping session took place in the rainy season and the second at the beginning of the dry season. The numbers of rats caught were statistically analysed to find correlations with factors as trapping day, crop height, soil type, average distance between the stone bunds, average height of the stone bunds, total length of stone bunds per hectare and total volume of rock fragments in bunds and heaps per hectare. The trapped rodents were identified in the field to genus level, their reproductive condition was noted, tissue samples were taken and the carcasses were preserved as voucher specimens. The specimens were later identified to species level in the laboratory using skull morphology and molecular analyses. The reproductive condition of the animals was compared between the two trapping sessions.

\subsection{Impacts of stone bunds on crop yield and economic valuation}

Crop yield was measured in 143 plots in the (relatively dry) year 2002 at three positions (centre, upper and lower ends) in each plot, and the computed increment in crop yield was weighed against space occupied by bunds (Desta, 2003; Vancampenhout et al., 2006). Since nearly all farmland is terraced in the study area, the plot's centre has been used as a conservative reference for the unterraced situation (Dercon et al., 2003; Turkelboom et al., 1999). The increment in crop yield was then expressed in monetary terms and compared to costs of stone bund building.

Additionally, the height of shoots of cereal crops from the ground surface to the tip of the ear was measured at the same three positions at 17 plots. This measurement was repeated for 10 shoots per field position (Vancampenhout, 2003). 


\subsection{Participatory assessment of farmers' acceptance}

Studies in six villages allowed assessing farmers' participation in the implementation and acceptance of stone bunds (Gebremedhin, 2004). For this reason, Naudts (2002) lived with local farmers in two villages for about 2 months. Participation in different agricultural activities, as well as several group discussions and 87 individual interview sessions, generated a clear idea of the farming practices in these two villages, as well as of the perceptions of the farmers with respect to stone bunds.

\section{Effectiveness of stone bunds for soil and water conservation}

\subsection{Soil erosion control}

Average sediment accumulation rate behind stone bunds was $58 \pm 34 \mathrm{t} \mathrm{ha}^{-1}$ year $^{-1}$. Mean total annual soil loss due to sheet and rill erosion was $57 \pm 26 \mathrm{t} \mathrm{ha}^{-1}$ year $^{-1}$ while the average tillage erosion rate is $19 \mathrm{t} \mathrm{ha}^{-1}$ year $^{-1}$. Thus, $76 \%$ of the total soil loss is trapped by the bunds (Fig. 4). Tillage erosion is mainly induced by the bunds so that the effective soil loss reduction by the bunds is $68 \%$ of the soil loss due to sheet and rill erosion. From the data reported above, the overall Universal Soil Loss Equation's $P$-factor (i.e. the support practice factor indicating reduced soil erosion potential due to farming practices and conservation measures) for stone bunds was estimated at 0.32 (Desta et al., 2005). Mati and Veihe (2001), while stating that "experimentally derived $P$ factor values in East and West Africa are few, partly due to the difficulties associated with setting up erosion plots that contain soil conservation measures", present a $P$ value of 0.18 for fanya juu terraces, stone lines and contour bunds. In Ecuador, stone bunds and grass strips established on steep runoff plots with loosened volcanic soils nearly eliminated runoff and erosion (De Noni et al., 2000) which is equivalent to a $P$-value of 0 . Considering that these low $P$-values were derived from measurements on experimental plots, our $P$-value of 0.32 may be taken as a realistic medium-term value (up to 20 years) for stone bunds on farmers' fields in the Ethiopian Highlands.

It should be kept in mind that considerable amounts of soil are still lost from terraced cropland, on average $18 \mathrm{t} \mathrm{ha}^{-1}$ year $^{-1}$. Indeed, sediment accumulation rates increase with slope gradient and bund spacing, but decrease with bund age (Desta et al., 2006). Especially when the depression behind the bunds gets filled with sediment, their trapping efficiency strongly decreases (Desta et al., 2005). New stone bunds are particularly effective in trapping transported sediment, but regular maintenance and increase in height of the bunds is necessary to maintain their effectiveness. A somewhat higher $P$-value can therefore be expected when the considered time span is increased.

One-metre-wide grass strips proved as effective as stone bunds to control soil erosion on slopes $<0.1$, but accumulation rates were less than half of those behind stone bunds on slopes of 0.25-0.3 (Nyssen, 2001).

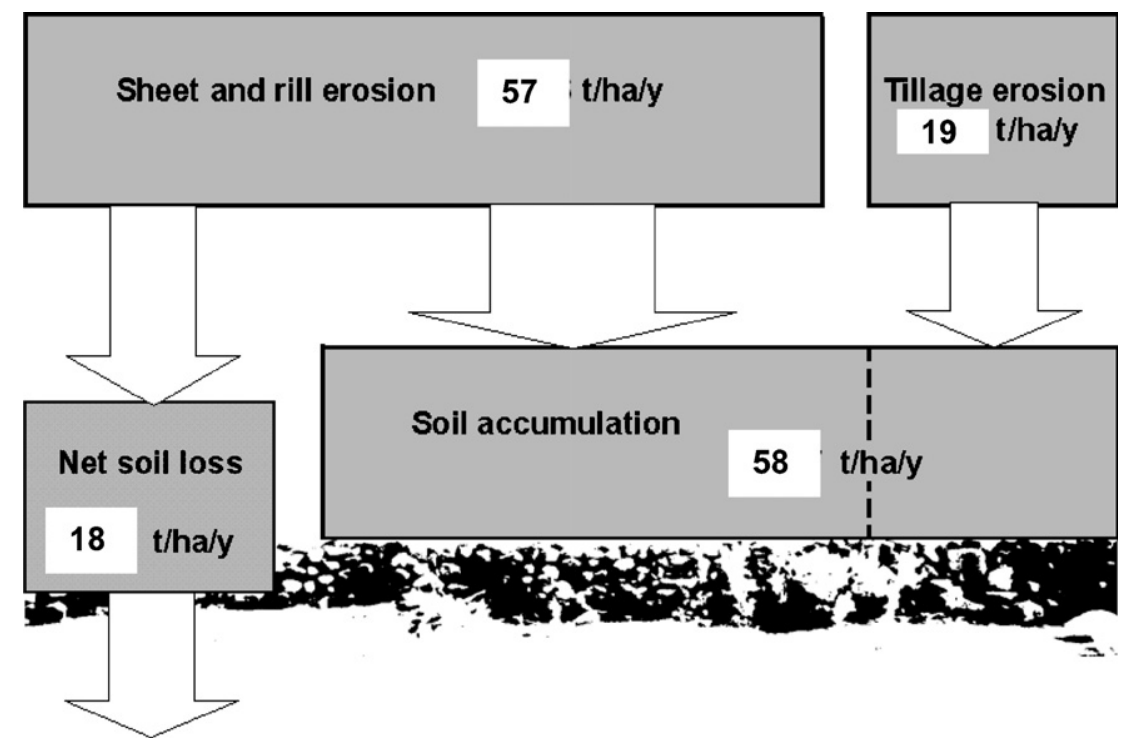

Fig. 4. Average sediment budget for cropped plots with stone bunds in Tigray Highlands (after Desta, 2003). 


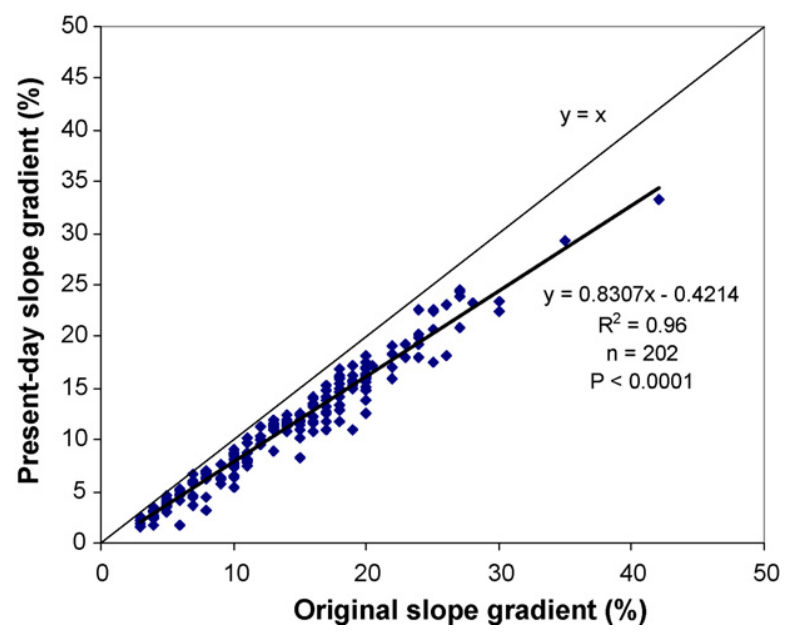

Fig. 5. New slope gradient induced by stone bund building, in relation to slope gradient before bund building.

Stone bunds are also effective in reducing the slope gradient of the land between the bunds and in reclamation of steep land. Since sediment is accumulating behind the bunds, the original slope gradients of the plots are reduced. The mean slope gradient of the 202 studied plots changed from $14.1 \%$ to $11.2 \%$, in $3-21$ years, which made the land more suitable for cultivation than before bund building (Fig. 5). The slope gradient of the plots decreases annually at an average rate of 0.33 $( \pm 0.21) \%$. Generally, the concomitant increase of slope gradient at the very position of the stone bund does not lead to increased erosion since (a) a large part of the runoff is trapped behind the bunds and (b) the stony nature of the bunds and adjacent grass strips protect it from erosion; however, occasionally stone bund failure and slumping may occur.

\subsection{Water conservation}

Vancampenhout (2003) found that stone bunds enhance soil moisture storage on both sides of the bund, especially on loamy and sandy soils. The effect is especially important at greater depth: $0.05-0.1 \mathrm{~g} \mathrm{~g}^{-1}$ more soil moisture at a depth of $1-1.5 \mathrm{~m}$ persists for at least 2 months after the end of the rainy season (Fig. 6, Vancampenhout, 2003). This contrasts with the common understanding that in situ water conservation techniques lead to improved soil moisture at shallow depth. Indeed, schematic presentations of the impact of conservation techniques on soil moisture profiles (Hudson, 1987; Schwab et al., 1993) systematically show strong soil moisture increase in the upper decimetres of the soil profile. However, water that has percolated to greater depth is less available for evapotranspiration and hence offers possibilities for deeper rootzone recharge (Scott et al., 2000) and groundwater recharge (Prinz and Malik, 2005).

\section{Side effects of stone bunds}

\subsection{The issue of soil fertility gradients induced by stone bund building}

Development of soil fertility gradients caused by tillage erosion and sediment deposition is often mentioned as the major drawback of stone bund implementation, as it would result in a dramatic lowering of crop yield. In our study area, levels of $\mathrm{P}_{\mathrm{av}}, \mathrm{N}_{\text {tot }}$ and $\mathrm{C}_{\text {org }}$ in the plough layer were found to be highly variable between plots and were mainly determined by small-scale soil and environmental features, plot history and management (Vancampenhout
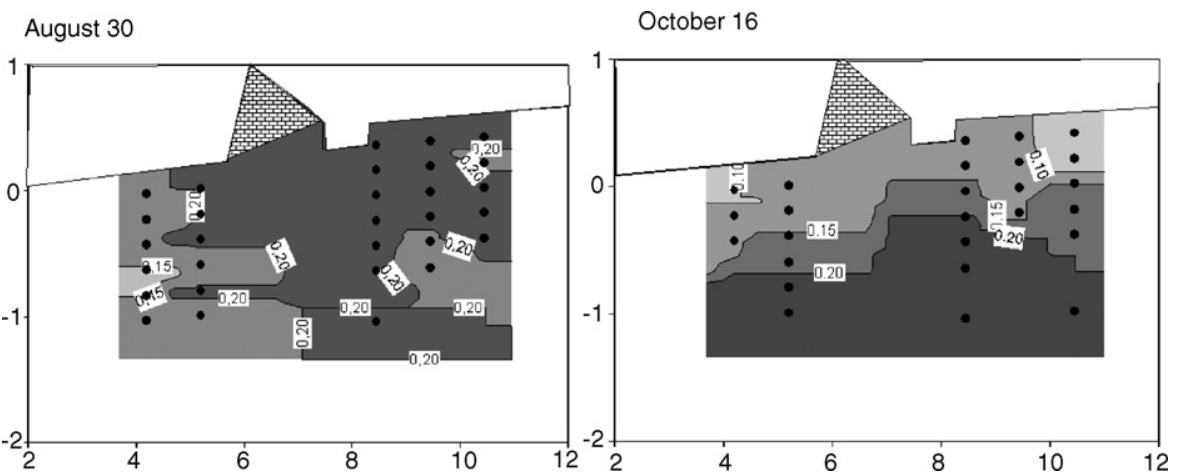

Fig. 6. Impact of stone bunds on soil moisture distribution in 2002. Cross-sections with depth and horizontal distance in $\mathrm{m}$. Black dots correspond to the position of soil samples analysed for moisture content $\left(\mathrm{g} \mathrm{g}^{-1}\right)$; curves of equal moisture content were interpolated between these points. Especially in limestone areas, soil moisture is enhanced up- and downslope of the bunds (darker colour on the cross-sections) and residual moisture stays high several months after the end of the rainy season (right) (after Vancampenhout, 2003). 
et al., 2006). After correcting for this "plot effect", a significant relationship was found between the position in the plot relative to the stone bund and levels of $\mathrm{P}_{\mathrm{av}}$ and $\mathrm{N}_{\text {tot }}$, which are higher near the lower stone bund, especially on limestone parent material. For $\mathrm{C}_{\text {org }}$ and on basalt-derived soils in general no significant relationship was found (Fig. 7). Soil fertility gradients, however present, are not problematic and can be countered by adapted manuring management. Only in some areas where a calcaric or calcic horizon is present at shallow depth (around 7\% of the study area-Nyssen et al., $2006 \mathrm{~b}$ ), care should be taken. The fact that truncation of the soil profile at the lower side of the bund does not lead to important soil fertility decrease at the upper side of the plot is mainly due to the fact that the dominant soil types in the study area (i.e. Regosols, Vertisols and Vertic Cambisols) do not have pronounced vertical fertility gradients. Regosols are composed of thick layers of recent colluvial deposits or consist of relatively unaltered parent material from which the top horizons have been completely eroded. The soils with vertic properties undergo a continuous 'churning', which leads to strong homogenisation of the top $80 \mathrm{~cm}$ of the soil profile (Mermut et al., 1996). Similar absence of vertical soil fertility gradient in homogenised deposits has been reported for various regions in the world (Dregne, 1995; Lal, 2001). Our findings are not necessarily in contradiction with the existence of lateral fertility gradients elsewhere (Turkelboom et al., 1997, 1999; Herweg and Ludi, 1999; Dercon et al., 2003; Dabney et al., 1999), since these involved soil types

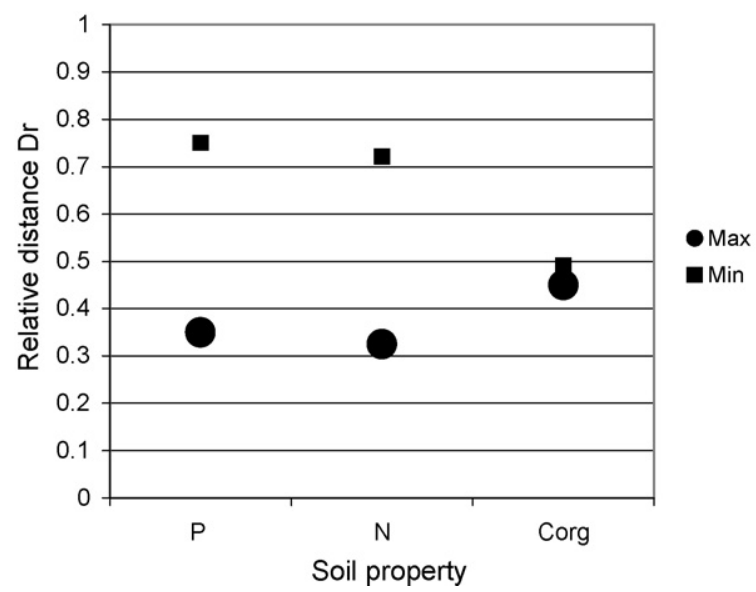

Fig. 7. Relation between the relative position in the plot ( $y=0$ for the position immediately upslope of the lower bund; $y=1$ for the location at the foot of the upper bund) and the average minimum and maximum values of three soil fertility parameters $\left(\mathrm{P}, \mathrm{N}, \mathrm{C}_{\mathrm{org}}\right)$. The closer these values are to each other, the less is the soil fertility gradient expressed (after Vancampenhout et al., 2006). with clearly differentiated horizons. Furthermore, this result would also indicate that on deep homogenous soils without vertical fertility gradients, soil erosion may lead in some cases to high nutrient losses (Nigussie et al., 2006), but not to decreased soil fertility. This adds on to recent reconsiderations on erosion tolerance (Sparovek and De Maria, 2003).

\subsection{Consequences of excessive rock fragment removal for stone bund building}

If 'overdone', stone bund building may lead to excessive removal of rock fragments from the field surface. Total clearing of rock fragments from the land led to an up to three-fold increase in water erosion rates (Table 1). However, the resulting positive relationship between rock fragment cover and grain and straw yield was weak. This might be explained by the fact that the experimental plot did not suffer from drought in the years when the experiment was carried out, due to favourable soil and climatic conditions. Detailed analysis (Nyssen et al., 2001) indicated that the cover by medium and large rock fragments $(>2 \mathrm{~cm}$ diameter) shows an optimal percentage cover above which crop yields decrease, whereas there was a linear increase of crop yield with increasing cover by small rock fragments ( $<2 \mathrm{~cm}$ across). The use of stone rich soil, rather than rock fragments, as backfill for bunds alleviates the problem of rock fragment cover removal.

\subsection{Do stone bunds induce an excessive accumulation of runoff or sediment?}

Crop damage related to runoff concentration and sediment accumulation induced by stone bunds (Fig. 8) was only found over $60 \mathrm{~m}$ along $4 \mathrm{~km}$ of studied bunds.

Table 1

Soil fluxes due to water erosion on experimental plots with different treatments in terms of rock fragment removal in $1999^{\text {a }}$ (after Nyssen et al., 2001)

\begin{tabular}{lcll}
\hline Treatment $^{\mathrm{b}}$ & $\begin{array}{l}\text { Rock fragment } \\
\text { cover }^{\mathrm{c}}(\%)\end{array}$ & $\begin{array}{l}\text { Slope gradient } \\
\left(\mathrm{m} \mathrm{m}^{-1}\right)\end{array}$ & $\begin{array}{l}\text { Soil flux } \\
\left(\mathrm{kg} \mathrm{m}^{-1} \mathrm{year}^{-1}\right)\end{array}$ \\
\hline All & $0.6( \pm 1.3)$ & $0.13( \pm 0.01)$ & $27.4( \pm 5.7)$ \\
Half & $13.8( \pm 2.4)$ & $0.12( \pm 0.02)$ & $19.6( \pm 10.4)$ \\
Control & $18.1( \pm 3.7)$ & $0.12( \pm 0.01)$ & $8.7( \pm 4.6)$ \\
\hline
\end{tabular}

\footnotetext{
${ }^{\text {a }}$ Means of treatments (standard deviation between brackets).

b Treatment given to the subplots at the start of the experiment. All $=$ all rock fragments removed; half $=50 \%$ of the rock fragments removed; control $=$ no rock fragments removed .

${ }^{c}$ Rock fragment cover measured on 27 May 1999, i.e. just after the first tillage operation.
} 


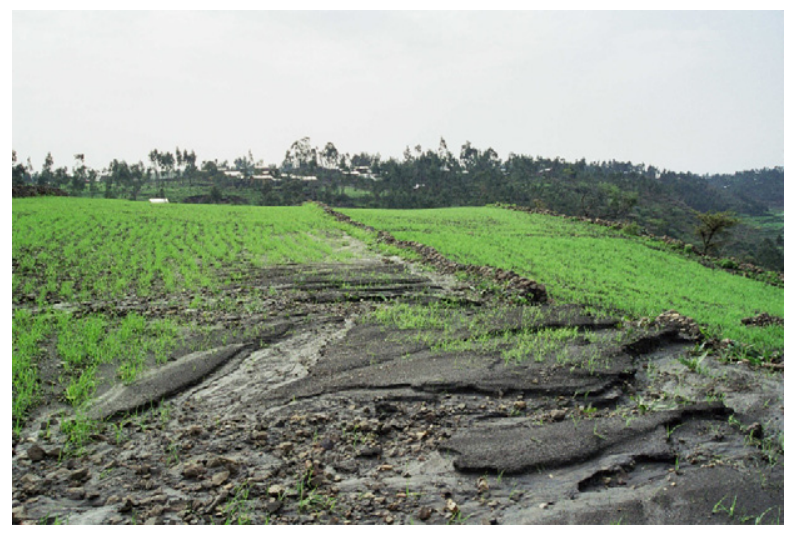

Fig. 8. Crop burial due to rapid accumulation of sediment behind a stone bund near Hagere Selam. This was the most extreme case in our study, where sediment was transported by runoff diverted from a rural road. Such phenomena only occur along $1.2 \%$ of the $4-\mathrm{km}$ length of representative stone bunds that were investigated.

Main causes are (1) runoff diverted by footpaths and plan concavities onto farmland which leads to high sediment deposition behind the first stone bund encountered and (2) localised improper bund alignment, leading to graded structures that concentrate runoff to one spot. Crop damage after bund building is, according to the farmers, an order of magnitude smaller than crop damage caused by rill erosion before bund building (Vancampenhout, 2003).

\subsection{Are stone bunds a safe harbour for rodents?}

D'aes (2006) investigated whether there is a rationale for the perception that stone bunds can be additional safe hiding places for rats, which may lead to rat infestations. It is known from other regions in Ethiopia that rats may consume up to $20 \%$ of the cereal crop in some years (Afework and Leirs, 1997; Workneh et al., 2004). During the two sessions, a total of 191 rodents and insectivores were trapped, at a density of 424 per trapping session per field plot of $60 \mathrm{~m} \times 60 \mathrm{~m}$. The majority of these were the multimammate mouse Mastomys awashensis (60\%) and the grass rat Arvicantis niloticus (31\%). As phenological growth stage advanced, the number of pregnant female $M$. awashensis increased dramatically from $0 \%$ to $74 \%$ between the two trapping sessions, which indicates seasonal breeding and future increases in numbers, but the data did not suggest seasonal reproduction for $A$. niloticus. Both species showed a decline in numbers in the second trapping session. The number of $A$. niloticus rats was significantly affected by the height of the crop $(P=0.009)$ and the length of stone bunds per hectare
$(P=0.045)$, but not by soil type, distance to stone bunds and stone bund height or volume (D'aes, 2006). For $M$. awashensis, none of these factors explained the number of rodents. A. niloticus is a diurnal rodent species and may have more need for cover against predators than nocturnal species such as Mastomys (Workneh et al., 2004). In the pilot study, the stone bunds seemed to have a minor impact only on rodent density, basically affecting only one species and explaining only $9 \%$ of the variation in that species. It is worth noticing that, as a diurnal species that make runways, these grass rats are more visible to the farmers.

\section{Impact on crop yield and scope for fodder production}

On plots with stone bunds (between 3 and 21 years old) there is an average increase in grain yield of 53\% in the lower part of the plot, as compared to the middle and upper parts (Table 2). This increase in crop yield is significant for all crop types and for most soil types (Desta, 2003; Vancampenhout et al., 2006). On average, and taking into account space occupied by the bunds, stone bunds led to crop yield increases from 632 to $683 \mathrm{~kg} \mathrm{ha}^{-1}$ for cereals, from 501 to $556 \mathrm{~kg} \mathrm{ha}^{-1}$ (11\%) for Eragrostis tef and from 335 to $351 \mathrm{~kg} \mathrm{ha}^{-1}$ for Cicer arietinum. The bunds have led in 2002 to an average yield improvement from 0.584 to $0.65 \mathrm{t} \mathrm{ha}^{-1}$. At current stone bund density, maintenance rates and building expenditure, stone bund building costs $€ 13.6 \mathrm{ha}^{-1}$ year $^{-1}$, which is nearly the same as the financial benefits from yield improvement $\left(€ 13.2 \mathrm{ha}^{-1}\right.$ year $^{-1}$ ). Moreover, the straw height of cereal crops increased significantly $(\alpha=0.01)$ in the lower part of the plot, from an average of 60.9 to $72.5 \mathrm{~cm}$ per shoot (Vancampenhout, 2003). These are arguments for continued public investment in stone bund building. Moreover, the observed deeper rootzone recharge indicates that, with controlled grazing, the stone bund areas can be made more productive through fodder tree planting, as proven in a participatory experiment introducing agroforestry on stone bunds (Hailu, 2003) and experimented in the May Zegzeg Integrated Watershed Management Project (Nyssen et al., 2003). Regular pruning of trees for livestock fodder allows avoiding negative effects of shade from the trees on the crops close to the bund. These results also indicate that stone bunds may contribute in solving fodder production problems, which are of major importance in the Ethiopian highlands (Berhanu et al., 2004). 
Table 2

Average crop response measured at the sediment accumulation zone, central zone and erosion zone of 143 cropped plots

\begin{tabular}{|c|c|c|c|}
\hline Crop response & $n$ & Position in plot & $\begin{array}{l}\text { Average crop } \\
\text { response }\left(\mathrm{t} \mathrm{ha}^{-1}\right)\end{array}$ \\
\hline All plots & 143 & $\begin{array}{l}\text { Accumulation zone } \\
\text { Central zone } \\
\text { Erosion zone }\end{array}$ & $\begin{array}{l}0.83 \mathrm{a}^{\text {**** }} \\
0.55 \mathrm{~b}^{\text {**** }} \\
0.54 \mathrm{~b}^{\text {*** }}\end{array}$ \\
\hline Plots on basalt & 98 & $\begin{array}{l}\text { Accumulation zone } \\
\text { Central zone } \\
\text { Erosion zone }\end{array}$ & $\begin{array}{l}0.95 \mathrm{a}^{\text {**** }} \\
0.60 \mathrm{~b}^{\text {**** }} \\
0.59 \mathrm{~b}^{\text {*** }}\end{array}$ \\
\hline Plots on limestone & 45 & $\begin{array}{l}\text { Accumulation zone } \\
\text { Central zone } \\
\text { Erosion zone }\end{array}$ & $\begin{array}{l}0.56 \mathrm{a} \\
0.44 \mathrm{a} \\
0.42 \mathrm{a}\end{array}$ \\
\hline Plots with cereals & 80 & $\begin{array}{l}\text { Accumulation zone } \\
\text { Central zone } \\
\text { Erosion zone }\end{array}$ & $\begin{array}{l}1.00 \mathrm{a}^{* * *} \\
0.63 \mathrm{~b}^{\text {**** }} \\
0.61 \mathrm{~b}^{\text {**** }}\end{array}$ \\
\hline Plots with Eragrostis tef & 37 & $\begin{array}{l}\text { Accumulation zone } \\
\text { Central zone } \\
\text { Erosion zone }\end{array}$ & $\begin{array}{l}0.79 a^{*} \\
0.50 b^{*} \\
0.53 b^{*}\end{array}$ \\
\hline Plots with Cicer arietinum & 15 & $\begin{array}{l}\text { Accumulation zone } \\
\text { Central zone } \\
\text { Erosion zone }\end{array}$ & $\begin{array}{l}0.52 \mathrm{a}^{* *} \\
0.34 \mathrm{~b}^{* *} \\
0.29 \mathrm{~b}^{\text {** }}\end{array}$ \\
\hline
\end{tabular}

Separate results are indicated for different parent materials and different crops (after Vancampenhout et al., 2006). a, b = Kruskal-Wallis non parametric pairwise comparison grouping.

* Different letters (a and b) indicate significantly different groups $(\alpha=0.1)$.

** Different letters (a and b) indicate significantly different groups $(\alpha=0.05)$.

*** Different letters (a and b) indicate significantly different groups $(\alpha=0.01)$.

\section{Farmers' perception of stone bunds}

Protection from the soil against erosion is the best known advantage of stone bunds (cited by about $90 \%$ of the interviewed farmers) (Naudts, 2002). Accumulation of (often very fertile) sediment and increased infiltration of runoff water are answers that are given by about $20 \%$ of the interviewed farmers. The most cited (26\%) disadvantage of stone bunds is the fact that they would attract rats. In the village of Agerba (located on basaltic parent material with rather fertile soils), $18 \%$ of the farmers estimate that the stone bunds take too much space in the middle of their fields. The farmers of Hechi (located on less fertile soils derived from limestone) did not give this answer. Table 3 shows that a majority of the farmers in the Tembien Highlands performs, by their own initiative, maintenance works on the stone bunds in their fields (79\% in Agerba, 93\% in Hechi). A third topic concerned the willingness to accept an additional stone bund between two already existing stone bunds on arable land. On average, $92 \%$ of the farmers would accept, with again $100 \%$ in the limestone village of Hechi. The overall farmer's perception of stone bunds is presented in Table 4.

Unlike the moist areas of the Central and Southern Ethiopian Highlands, where investment in SWC may not be profitable at farm level, although social benefits are positive (Bekelle and Holden, 1999; Bereket and Asafu-Adjaye, 1999), improved crop yield in our study area is certainly the major explanation of the farmers' positive attitude. In addition, one of the major conclusions of the evaluation of the Soil Conservation

Table 3

Farmers' attitudes towards stone bunds (after Naudts, 2002)

\begin{tabular}{llrr}
\hline & \multicolumn{2}{l}{ This year, did you do some maintenance works on the stone bunds in your fields (rebuilding collapsed parts, } \\
& arranging stones, $\ldots)$ ? & Village of Hechi $(n=28)$ & Total $(n=61)$ \\
\cline { 2 - 4 } & Village of Agerba $(n=33)$ & $26(92.9 \%)$ & $52(85.2 \%)$ \\
Maintenance & $26(78.8 \%)$ & $2(7.1 \%)$ & $9(14.8 \%)$ \\
\hline
\end{tabular}


Table 4

Synthesis: farmers' perceptions of stone bunds (after Naudts, 2002)

\begin{tabular}{llll}
\hline & $\begin{array}{l}\text { Village of } \\
\text { Agerba }(n=33)\end{array}$ & $\begin{array}{l}\text { Village of Hechi } \\
(n=28)\end{array}$ & $\begin{array}{l}\text { Total } \\
(n=61)\end{array}$ \\
\hline Positive & $20(60.1 \%)$ & $26(92.9 \%)$ & $46(75.4 \%)$ \\
Negative & $13(39.4 \%)$ & $2(7.1 \%)$ & $15(24.6 \%)$ \\
\hline
\end{tabular}

Research Programme by Herweg and Ludi (1999) is that successful SWC is frequently connected with the following attributes: technical feasibility and adaptability, ecological soundness, economic viability and social acceptance. These authors, as well as Bewket and Sterk (2002) stress the need to involve the farmers in all stages of experimentation with SWC technology. This will certainly contribute to the development of more productive technologies, i.e. combinations of agronomic, biological and mechanical techniques, which are more attractive to the farmers compared to techniques, which are simply targeted at reducing erosion (ElSwaify and Hurni, 1996).

\section{Conclusions}

From the technical, ecological and economical point of view, the extensive use of stone bunds in the Tigray Highlands, involving people's participation, is a positive operation. Soil loss by sheet and rill erosion is decreased by $68 \%$, infiltration is enhanced and crop yields are slightly improved. The effectiveness for soil conservation still seems less than what has been found elsewhere, but here one will bear in mind that we measured medium-term (3-21 years) effectiveness in the real field situation, whereas most other studies were conducted on young structures under optimal management. New findings in our studies are also the recharge of the deep root zone around stone bunds and the near absence of soil fertility gradients, which is related to the dominance of relatively homogenous soils.

A recommendation resulting from the study on rock fragment removal is to rely on the farmers' experience: smaller rock fragments should never be removed from the fields' surface during soil and water conservation works; instead rock fragment rich soil can be used to top the stone bunds. This is done in the case of 'stone faced trench' building (Fig. 9).

Rats appear to be an important pest all over the Tigray Highlands, which needs to be treated as such. The stone bunds have a minor impact only on the rats, basically affecting one of the two dominant species and explaining only $9 \%$ of the variation in that species.

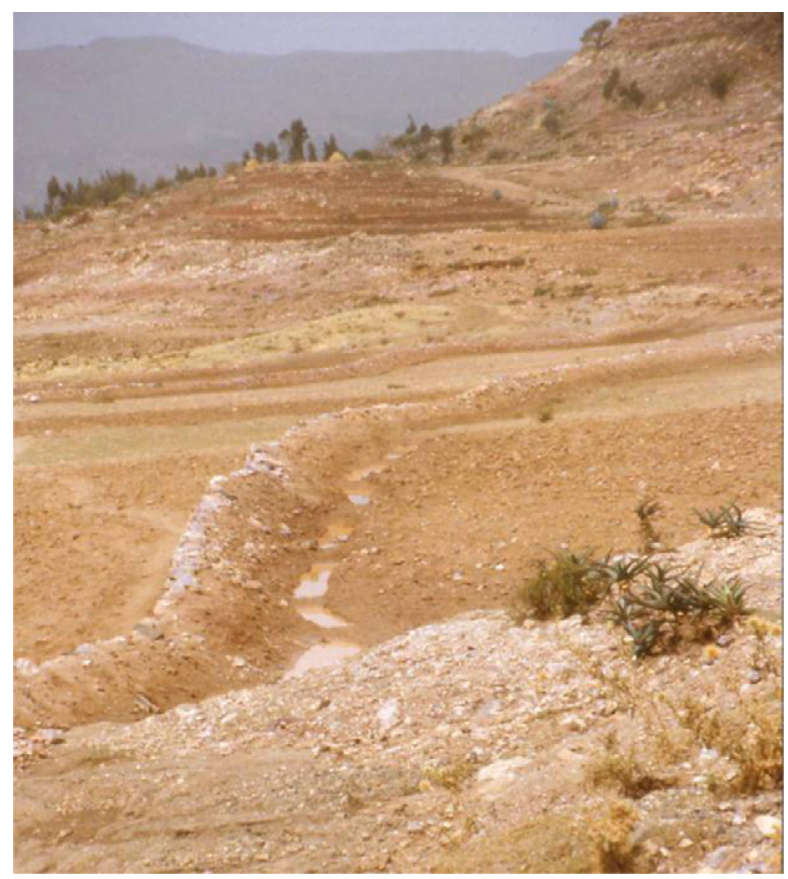

Fig. 9. The building of stone faced trenches, i.e. stone bunds along tied ridges, allows the use of rock fragment rich soil as backfill for the stone bunds and enhances infiltration.

No negative effects of stone bund undermining their sustainability were found in this study. Soil erosion on the other hand, poses a major threat to agricultural productivity. Stone bund implementation therefore is of vital importance in fighting erosion and establishing sustainable land management practices in the Ethiopian Highlands. Overall, 75.4\% of the farmers are in favour of stone bund building on their land, which is a clear indication that the local community perceives this conservation measure as being beneficial.

Since the positive impact of stone bunds on crop yield is mostly concentrated around the stone bunds, future research and development of conservation technologies in these semi-arid mountain areas should also focus on in situ SWC at the area located between the stone bunds. In the study area, research on conservation agriculture with permanent beds and stubble management (Nyssen et al., 2006c) aims at filling this gap.

\section{Acknowledgements}

The studies synthesised here were all carried out in the framework of Zala-Daget project, a co-operative research programme between Mekelle University and Relief Society of Tigray (Ethiopia), K.U. Leuven and Africamuseum (Belgium), funded by the Belgian Development 
Co-operation through the Belgian Flemish Interuniversity Council (VLIR). Numerous farmers agreed to share their knowledge with us. The local Agricultural Office, REST (Relief Society of Tigray) branch, May Zegzeg Integrated Watershed Management Project office and the authorities of the concerned villages and district facilitated the research. This paper benefited much from comments given by participants in the "Fourth International Conference on Land Degradation" (Cartagena, Murcia, Spain, 12-17 September 2004), and in Eurosoil (Freiburg, Germany, 4-12 September 2004), as well as from comments on an earlier version of this paper by Rattan Lal and two anonymous reviewers.

\section{References}

Afework Bekele, Leirs, H., 1997. Population ecology of rodents of maize fields and grasslands in Central Ethiopia. Belgian J. Zool. 127.

Arkin, Y., Beyth, M., Dow, D.B., Levitte, D., Temesgen Haile, Tsegaye Hailu, 1971. Geological Map of Mekele Sheet Area ND 37-11, Tigre Province, 1:250.000, Imperial Ethiopian Governement, Ministry of Mines, Geological Survey, Addis Ababa.

Bekelle Shiferaw, Holden, S., 1999. Soil erosion and smallholders' conservation decisions in the Highlands of Ethiopia. World Dev. 27 (4), 739-752.

Bereket Araya, Asafu-Adjaye, J., 1999. Returns to farm-level soil conservation on tropical steep slopes: the case of the Eritrean Highlands. J. Agric. Econ. 50, 589-605.

Berhanu Gebremedhin, Pender, J., Girmay Tesfay, 2004. Collective action for grazing land management in crop-livestock mixed systems in the highlands of northern Ethiopia. Agric. Syst. 82, 273-290.

Bewket, W., Sterk, G., 2002. Farmers' participation in soil and water conservation activities in the Chemoga Watershed, Blue Nile basin, Ethiopia. Land Degrad. Dev. 13, 189-200.

BoANR, 1997. Water and Soil Conservation, Forestry Development. Manual for Agricultural Cadres. Lekatit 1989 (Eth. Cal.) (in Tigrigna). Bureau of Agriculture and Natural Resources, Mekelle, $33 \mathrm{pp}$.

BoANR, 2002. Soil and Water Conservation Annual Summary Report (in Tigrigna). Bureau of Agriculture and Natural Resource Development, Mekelle.

Bosshart, U., 1997. Catchment Discharge and Suspended Sediment Transport as Indicators of Physical Soil and Water Conservation in the Mayketin Catchment, Afdeyu Research Unit. A Case Study in the Northern Highlands of Eritrea. Bern, SCRP. Research Report 39, $137 \mathrm{pp}$.

Dabney, S.M., Lui, Z., Lane, M., Douglas, J., Zhu, J., Flanagan, D.C., 1999. Landscape benching from tillage erosion between grass hedges. Soil Till. Res. 51, 219-231.

D'aes, M., 2006. Impact van het bouwen van stenen muurtjes op rattenpopulaties en-schade in het Noordelijk Ethiopisch Hoogland (in Dutch). Unpublished MSc thesis, Evolutionary Biology Group, University of Antwerp, Belgium.

De Noni, G., Prat, C., Quantin, P., Viennot, M., Zebrowski, C., 2000. Erosion et conservation, après récupération, des sols volcaniques indurés de l'Equateur et du Mexique. Etude et Gestion des Sols 7, 25-36.
Den Biggelaar, C., Lal, R., Wiebe, K., Breneman, V., 2004. The global impact of soil erosion on productivity. I. Absolute and relative erosion-induced yield losses. Adv. Agronomy 81, 1-48.

Dercon, G., Deckers, J., Govers, G., Poesen, J., Sánchez, H., Vanegas, R., Ramínez, M., Loaiza, G., 2003. Spatial variability in soil properties on slow forming terraces in the Andes region of Ecuador. Soil Till. Res. 72, 31-41.

Descheemaeker, K., Nyssen, J., Rossi, J., Poesen, J., Mitiku Haile, Moeyersons, J., Deckers, J., 2006. Sediment deposition and pedogenesis in exclosures in the Tigray Highlands, Ethiopia. Geoderma 132, 291-314.

Desta Gebremichael, 2003. Effectiveness and sustainability of soil and water conservation bunds on cropland in the Tigray Highlands (Northern Ethiopia). Unpublished M.Sc. thesis, Department of Geography, Catholic University of Leuven, Belgium.

Desta Gebremichael, Poesen, J., Nyssen, J., Deckers, J., Mitiku Haile, Govers, G., Moeyersons, J., 2005. Effectiveness of stone bunds in controlling soil erosion on cropland in the Tigray highlands, Northern Ethiopia. Soil Use Manag. 21, 287-297.

Desta Gebremichael, Poesen, J., Nyssen, J., Deckers, J., Mitiku Haile, 2006. Effectiveness of stone bunds for sediment trapping on cropland in the Tigray highlands, Northern Ethiopia, with special reference to Dogua Tembien highlands. In: Taye Bekele, Belay Demissie, Selamyihun Kidanu, (Eds.), Proceedings of the Seventh Conference of the Ethiopian Society of Soil Science, Addis Ababa, 11-12 March 2004, pp. 25-66.

Dregne, H., 1995. Erosion and soil productivity in Australia and New Zealand. Land Degrad. Rehabil. 6, 71-78.

El-Swaify, S., Hurni, H., 1996. Transboundary effects of soil erosion and conservation in the Nile basin. Land Husbandry 1 (1-2), 7-21.

Gebremedhin Yihdego, 2004. The role of community participation in enhancing sustainable water and soil conservation management. MSc Thesis, Addis Ababa University.

Gebremedhin Yohannes, Herweg, K., 2000. Soil and Water Conservation-From Indigenous Knowledge to Participatory Technology Development. Lang Drück AG, Liebfeld, Bern, Switzerland.

Hailu Kiros, 2003. Participatory implementation of agroforestry in Tigray, Dega Tembien Woreda. Report of Supervised Enterprise Project, Department of Agricultural Extension, Alemaya University, Ethiopia, 31 pp.

Hengsdijk, H., Meijerink, G., Mosugu, M., 2005. Modeling the effect of three soil and water conservation practices in Tigray, Ethiopia. Agric. Ecosys. Environ. 105, 29-40.

Herweg, K., 1993. Problems of acceptance and adaptation of soil conservation in Ethiopia. In: Baum, E., Wolff, P., Zöbisch, M.A. (Eds.), Acceptance of Soil and Water Conservation Strategies and Technologies. Topics in Applied Resource Management, vol. 3. pp. 391-411.

Herweg, K., Ludi, E., 1999. The performance of selected soil and water conservation measures-case studies from Ethiopia and Eritrea. Catena 36 (1/2), 99-114.

Herweg, K., Stillhardt, B., 1999. The variability of soil erosion in the Highands of Ethiopia and Eritrea. Soil Conservation Research Project, Research Report 42. Centre for Development and Environment, University of Berne, $81 \mathrm{pp}$.

Hudson, N., 1987. Soil and water conservation in semi-arid areas. FAO Soils Bull. 57, 172.

Hutchinson, R.W., Engels, G.G., 1970. Tectonic significance of regional geology and evaporite lithofacies in northeastern Ethiopia. Phil. Trans. R. Soc. Lond. A. Math. Phys. Sci. 267, 313-330.

Lal, R., 1998. Soil erosion impact on agronomic productivity and environment quality. Crit. Rev. Plant Sci. 17, 319-464. 
Lal, R., 2001. Soil degradation by erosion. Land Degrad. Dev. 12, 519-539.

Mati, B.M., Veihe, A., 2001. Application of the USLE in a savannah environment: comparative experiences from East and West Africa. Singapore J. Trop. Geogr. 22 (2), 138-155.

Merla, G., 1938. I depositi intervulcanici. In: Merla, G., Minucci, E. (Eds.), Missione Geologica nel Tigrai. Reale Accademia d'Italia, Roma, pp. 332-336.

Merla, G., Abbate, E., Azzaroli, A., Bruni, P., Canuti, P., Fazzuoli, M., Sagri, M., Tacconi, P., 1979. A Geological Map of Ethiopia and Somalia (1973) 1:2.000.000 and Comment. University of Florence, Italy.

Mermut, A., Padmanhabham, E., Eswaran, H., Dasog, G.S., 1996. Pedogenesis. In: Ahmad, N., Mermut, A. (Eds.), Vertisols and Technologies for their Management. Elsevier, Amsterdam, pp. 43-61.

Morgan, R.P.C., 1995. Soil Erosion and Conservation, second ed. Silsoe College, Cranfield University.

Naudts, J., 2002. Les Hautes Terres de Tembien, Tigré, Ethiopie; Résistance et limites d'une ancienne civilisation agraire; Conséquences sur la dégradation des terres. Mémoire présenté en vue de l'obtention du Diplôme d'Agronomie Tropicale. CNEARC, Montpellier, $147 \mathrm{pp}$.

Nigussie Haregeweyn, Poesen, J., Nyssen, J., Verstraeten, G., de Vente, J., Govers, G., Deckers, J., Moeyersons, J., 2005. Specific sediment yield in Tigray-Northern Ethiopia: Assessment and semi-quantitative modelling. Geomorphology 69, 315-331.

Nigussie Haregeweyn, Poesen, J., Deckers, J., Nyssen, J., Mitiku Haile, Govers, G., Verstraeten, G., Moeyersons, J., 2006. Assessment and evaluation of sediment-bound nutrient export and associated costs from micro-dam catchments in Northern Ethiopia. Agriculture, Ecosystems and Environment, submitted for publication.

Nyssen, J. 2001. Erosion processes and soil conservation in a tropical mountain catchment under threat of anthropogenic desertification-a case study from Northern Ethiopia. Ph.D. thesis, KULeuven, Belgium, $380 \mathrm{pp}$.

Nyssen, J., Poesen, J., Mitiku Haile, Moeyersons, J., Deckers, J., 2000a. Tillage erosion on slopes with soil conservation structures in the Ethiopian highlands. Soil Till. Res. 57 (3), 115-127.

Nyssen, J., Mitiku Haile, Moeyersons, J., Poesen, J., Deckers, J., 2000b. Soil and water conservation in Tigray (Northern Ethiopia): the traditional daget technique and its integration with introduced techniques. Land Degrad. Dev. 11 (3), 199-208.

Nyssen, J., Mitiku Haile, Poesen, J., Deckers, J., Moeyersons, J., 2001. Removal of rock fragments and its effect on soil loss and crop yield, Tigray, Ethiopia. Soil Use Manag. 17, 179-187.

Nyssen, J., Moeyersons, J., Poesen, J., Deckers, J., Mitiku Haile, 2002. The environmental significance of the remobilisation of ancient mass movements in the Atbara-Tekeze headwaters, Northern Ethiopia. Geomorphology 49, 303-322.

Nyssen, J., Mitiku Haile, Descheemaeker, K., Deckers, J., Poesen, J., Moeyersons, J., Trufat Hailemariam, 2003. Promoting global watershed management towards rural communities: the May Zeg-zeg initiative. In: McCormick, P., Kamara, A., Girma Tadesse, (Eds.), Integrated Water and Land Management Research and Capacity Building Priorities for Ethiopia. Proceedings of a MoWR/EARO/IWMI/ILRI International Workshop, Addis Ababa, 2-4 December 2002. IWMI (International Water Management Institute), Colombo, Sri Lanka, and ILRI (International Livestock Research Institute), Nairobi, Kenya, pp. 192-195.

Nyssen, J., Vandenreyken, H., Poesen, J., Moeyersons, J., Deckers, J., Mitiku Haile, Salles, C., Govers, G., 2005. Rainfall erosivity and variability in the Northern Ethiopian Highlands. J. Hydrol. 311, 172-187.

Nyssen, J., Haregeweyn Nigussie, Descheemaeker, K., Desta Gebremichael, Vancampenhout, K., Poesen, J., Mitiku Haile, Moeyersons, J., Buytaert, W., Naudts, J., Deckers, J., Govers, G., 2006a. Comment on "Modelling the effect of soil and water conservation practices in Tigray, Ethiopia". Agric. Ecosys. Environ. 114, 407-411.

Nyssen, J., Naudts, J., De Geyndt, K., Mitiku Haile, Poesen, J., Moeyersons, J., Deckers, J., 2006b. Soilscapes and land use in the Northern Ethiopian Highlands: opportunities and constraints for smallholders. Soil Use Manag., in press.

Nyssen, J., Govaerts, B., Mintesinot Behailu, Mitiku Haile, Sayre, K., Tigist Oicha, Fisseha Meressa, Mekonnen Gebreslasie, Solomon Gebregziabher, Tewodros Gebregziabher, Fekadu Getnet, Nurhussen Taha, Wubetu Bihon, Poesen, J., Raes, D., Verplancke, H., Deckers, J., 2006c. Conservation agriculture: a further step in sustainable agricultural intensification in the Northern Ethiopian highlands. Mededelingen der zittingen KAOW, Bulletin des scéances ARSOM, in press.

Poesen, J., Torri, D., Bunte, K., 1994. Effects of rock fragments on soil erosion by water at different spatial scales: a review. Catena 23, 141-166.

Prinz, D., Malik, A., 2005. Runoff farming. WCA infoNET, 39 pp.

Schwab, G., Fangmeier, D., Elliot, W., Frevert, R., 1993. Soil and Water Conservation Engineering. Wiley, 508 pp.

Scott, R., Shuttleworth, W., Keefer, T., Warrick, A., 2000. Modeling multiyear observations of soil moisture recharge in the semiarid American Southwest. Water Resour. Res. 36 (8), 2233-2247.

Solomon Gebregziabher, Mouazen, A., Van Brussel, H., Ramon, H., Nyssen, J., Verplancke, H., Mintesinot Behailu, Deckers, J., De Baerdemaeker, J., 2006. Animal drawn tillage, the Ethiopian ard plough-Maresha: a review. Soil Till. Res. 89, 129-143.

Sparovek, G., De Maria, I., 2003. Multiperspective analysis of erosion tolerance. Scientia Agricola 60 (2), 409-416.

Tenge, A., De Graaff, J., Hella, J., 2004. Social and economic factors affecting the adoption of soil and water conservation in West Usambara highlands, Tanzania. Land Degrad. Dev. 15 (2), 99-114.

Turkelboom, F., Poesen, J., Ohler, I., Van Keer, K., Ongprasert, S., Vlassak, K., 1997. Assessment of soil erosion rates due to manual tillage on steep slopes in Northern Thailand. Catena 29, 29-44.

Turkelboom, F., Poesen, J., Ohler, I., Ongprasert, S., 1999. Reassessment of tillage erosion rates by manual tillage on steep slopes in northern Thailand. Soil Till. Res. 51, 245-259.

Vancampenhout, K., 2003. Consequences of stone bund implementation in the highlands of northern Ethiopia. Unpub. M.Sc. thesis, Department of Land Management, University of Leuven.

Vancampenhout, K., Nyssen, J., Desta, Gebremichael, Deckers, J., Poesen, J., Mitiku Haile, Moeyersons, J., 2006. Stone bunds for soil conservation in the northern Ethiopian highlands: impacts on soil fertility and crop yield. Soil Tillage Res. 90, 1-15.

Westphal, E., 1975. Agricultural Systems in Ethiopia. Centre for Agricultural Publishing and Documentation, Wageningen, 278 pp.

Wischmeier, W.H., Smith, D.D., 1978. Predicting Rainfall Erosion Losses: A Guide to conservation Planning. Agriculture Handbook, vol. 537. United States Department of Agriculture, Washington, $58 \mathrm{pp}$.

Workneh Gebresilassie, Afework Bekele, Gurja Belay, Balakrishnan, M., 2004. Microhabitat choice and diet of rodents in Maynugus irrigation field, northern Ethiopia. Afr. J. Ecol. 42 (4), 315321. 